\title{
Effect and significance of the study of Universities Ideological and political education in new media era
}

\author{
Dongna LV , Dong WANG , Bo AN \\ Hebei Chemical Industry Medicine Vocational and Technical College \\ Shijiazhuang 050026, China
}

\begin{abstract}
With the development of China's socialist market economy, ideological and political education in the new media environment has become one of the key research questions in the field of education, and it is also a hot issue. With the continuous development of Internet technology, and we improve the level of China's information technology, when new media that consequently conduct brings the current phase of opportunities of ideological and political work, but also it brings a lot of new problems, and it brings a certain degree of difficulty for Chinese Universities ideological and political education to carry out, which not only affects some basic elements of ideological and political education (including its theory of ideology and values) and has a strong impact on the concept communication, communication system and means of communication of ideological and political education. In this process, the majority of our ideological and political education theorists should proactively improve the ability to identify problems and solve problems, and they promote the development of ideological and political education. In this study, it summarizes new media features under the premise of effective definition for the general concept of the new media, it discusses the opportunities and challenges of the new media bring to the ideological and political education in our country on the basis of it, and it proposes specific measures to strengthen and improve the ideological and political education in the new media environment. In this paper, we use the theory and methods of many disciplines and we put carrying out ideological and political education in the new era of innovation environment as the purpose, and we actively explore ways and means that is fit for the environment and the development of ideological and political education in modern era, which have exploratory, prospective, cross-cutting features. Through this study, we hope to provide some reference for college about the use of new media technology to strengthen and improve the ideological and political education under the new situation.
\end{abstract}

Keywords- new media; ideological and political education; meaning

\section{INTRODUCTION}

We can date back to the 1960s about when people proposed the concept of new media. 1967 the director of the Institute of America CBS broadcasting network technology research $\mathrm{P}$ - Gold Mark published a report on the EVR (Electronic Video Recording, electronic recording) commodity program, which first proposed the "new media" (New Media) concept, which is used to refer to different traditional print media, broadcast on radio and image processing technology, television, movies and other media state.
So far, the "new media" concept was born, and raged from the United States to the world. The UN Committee used the concept of "new media" on the annual meeting of the in 1985 May, and this concept was referred to as the "fourth media" of the Internet, which means it is the fourth major traditional media after follows the newspapers, advertising, television and other three the mass media. Last century, UNESCO defined that the new media is the network media, but meaning of new media has been further expanded and extended with the passage of time and the development of technology. The new media has not been specific to a particular fixed media, which has been given the characteristics of the times and technology, so as to have a relative's allegations. "New" and "old", "modern" and "traditional" are always complementary, media as well. In the Han Dynasty, the world's first newspaper, "Di Bao" was born in China, the world's first radio station was born in 1920 in the United States, and the first TV was born in England in 1926. With the development of science and technology, production and dissemination of human information also change. New Media is a relative concept rather than an absolute concept, and every age has its own technical characteristics of the times to reflect their "new media." Comparing with the first generation of Internet Web before 2003, the ways to spread new business are emerging in second generation of the Internet, it has become platforms of more and more name creation, display and communication such as Tencent QQ and Microsoft's MSN that is as represents of instant messaging have become the most popular way of communication and exchange for people. Until the end of June 2011, the scale of China's instant messaging users is 385 million, with an increase of 32.51 million over the end of 2010 and an increase of $9.2 \%$. IM maintains upward trend, which increases to $79.4 \%$. Networking technology is used in audio and video file uploads and downloads, Internet TV, video broadcast and other areas, which make internet entering a new era of "audio-visual". Meanwhile, the new search engine not only has the traditional Web search functions, and it launched new blog search, video search, mobile search, personal search portal and other search methods, which have received a warm welcome from the majority of Internet users.

The concept of "New media" seems very different from radio, television, film and other traditional media in some foreign researchers and media institutions. American new media artist Lev• Manorvich, New Media Professor Vin Crosbie in Syracuse (Syracuse University)and the new US scientific journal WIRED magazines considered the socalled new media is not likely to have any of the media in the 
form of a special sense, it is the real meaning has evolved into a set of digital information and an implementation of the information flow that has achieve the " All to all communication ", or it said that it is information presentation with a combination of the characteristics of interpersonal communication in mass communication.

\section{NEW MEDIA FEATURES}

New Media is relative to the traditional media (such as newspapers, magazines, television, letters, radio and etc.), the new media is mainly relying on digital communications technology and interactive computer network technology and other new technologies, and it is a new medium that provides information dissemination to the public and share resource. For example, social networking services, wikis, digital television, virtual communities, blog, podcast, MMS etc belong to the category of new media. Compared with the traditional media, new media has the following distinctive features.

\section{A. Information dissemination is highly interactive}

New media is interactive when it is compared with traditional media, which is the most distinctive features. There is often a certain type of strong media as the dominant information dissemination under the conditions of traditional media, communication is the subject of one dollar and it is one-way communication model that is an communication "I say and you listen to"; and information dissemination is an interactive communication of mesh model with many to many interaction communication, the exchange of information is bidirectional in the new media era.

\section{B. Virtual trait of Individual participation and the contents of dissemination}

Virtual trait means virtual trait of Individual participation and the contents of dissemination. The identity of both the exchange of information would normally be "symbolic", and the real communications between people under conditions of real traditional media is replaced by this virtual nature of interpersonal communication in the new media environment. In addition, information publishers can use a variety of tools to modify a variety of images, pictures and texts as they wish, or "create" a variety of virtual information out of thin air under the conditions of the new media.

\section{Real-time and sharing of information dissemination}

Information dissemination expresses instantaneity in time, content and ways and it is more convenient and faster to make information dissemination under the conditions of the new media. People are able to take advantage of new media, and it is easy to realize the sharing of information and resources. Information dissemination breaks through limitations of the traditional media of information dissemination in time, space and speed, the contents of information dissemination are more rich and diverse, and openness is further strengthened.

\section{Personalized service in information dissemination}

Information dissemination of traditional media is the "opposite point" approach, and the information dissemination has the more prominent media personality under the new conditions, and it achieves "point" of information dissemination service. People can take advantage of new media to subscribe topics and content they're interested in and we can make personalized service fully according to individual needs, such as mobile newspapers, RSS feeds, etc.

\section{NECESSITY OF MEDIA LITERACY EDUCATION FOR IDEOLOGICAL AND POLITICAL EDUCATION WORKERS}

Most domestic scholars focus on students in the "media literacy education" issue inquiry, but they neglect Necessity of media literacy education for ideological and political education workers as digital television, Internet, 3G mobile phones and other new media have become college students learning an integral part of life. The dependency "People the media" in the "Survival media era" determines that media literacy is one of the basic qualities of excellent individuals to adapt to modern society; in addition, the way of thinking, behavior and interaction characteristics of college students determines that media literacy is the essential quality of the ideological and political education workers in new media era; and the ideological and political education workers for selfimprovement and self-development purposes in order to maintain demand for education "discourse dominance 'status determines that it's necessary for them to apply for media literacy education.

\section{THE IMPACT OF NEW MEDIA ON IDEOLOGICAL AND POLITICAL EDUCATION}

New media as an industry is synthesis of the form and content, means and goals. Development of new media develops under business model, so it has a dynamic motivation to develop, it covers all the traditional culture including business, entertainment, communications, entertainment, etc. in the contents, so that the new media is the world, but the world become new media. Charm of new media technologies and rich content help them to get the adoration from college students of all ages, and they even capture their souls, so we can say, it is difficult to get young people's self-identity especially the undergrads, if the world can't fuse with new media. Universities put Ideological and political education theory class as the main channel, the integration of new media and content is limited, mainly textbooks makes big move, and then they add some appropriate pictures and video in the textbooks, which can not fully attract college students. There are a lot of theory classes that still maintain in the "classic" of knowledge and ideas, unless a teacher has artistic talent, this would certainly make students drowsy. In the main position of ideological and political education, the content is relatively simple, and the main is television information of revolution themes. Practice has proved that this kind of contents can not meet the needs of society and the state. For example, in 2012 after Japan makes the Diaoyu Islands nationalization outrageously, 
young people continue to stir parade impulse with the need to express angry, in the streets in Xi'an, Qingdao and other cities, the crimes occurred serious harm the social order, and this shows Patriotisms Education that we have always implemented doesn't adjust th

eir teach contents to meet the needs of the development and forms, and it didn't take rational patriotism as the basic content of the patriotic education. In this aspect, the ideological and political education apparently walks behind the social media and social media and the majority of scholars have gone acutely from the social order, they adjust the specific content of patriotism with the fundamental interests of the country, even they proposed a "new patriotism" which it is rational patriotism peace. But these new ideas can only touch the idea of college students through new media skills, and then they make react. Therefore, the ideological and political education has been challenged from the content, the university can not regard themselves as in important places, that he is the sole creator of advanced culture, if they do not change this attitude, it is clear that he can only fall further behind, and it is difficult to bear ideological education of college students.

\section{SIGNIFICANCE OF NEW MEDIA IN IDEOLOGICAL AND POLITICAL EDUCATION}

\section{A. It requires educators to transform education concept under the new media environment}

In today's era, with the development and maturing of new media technologies, workers of university ideological and political education must master the actual needs of diverse exchanges, they learn about new media and acknowledge new media accreditation, they introduce new media and start political education with new media. Generally speaking, the ideological and political educators have a lot of differences with college students in age, so they should know what the contemporary college students play, think, and want to do. Then taking this as premise, then we make teaching content richer, while the university will also accelerate the transformation of education ideas and the innovative educational steps, we use methods college students accept and in line with their habits, psychological state of education, then we certainly make sure the dominant position of students as the basis to carry out educational work. Today, student publications, school newspapers and magazines and other traditional media have been turning to electronic networks, universities have created websites including BBS forums, message boards and other modules with the technical support of social networking sites to build a common platform with a distinctive ideas about Political Education Public homepage. Ideological and political education workers also can use blog, QQ, microblog and SMS, etc. and to communicate with students, and make comments about the cases student pay attention to and control their dynamic thoughts. These measures are made for diversified education for expanded exploration.
B. To improve the recipients' sense of belief about those who pass the ideological and political education communicators, thereby to enhance the dissemination of results with the new media

From the things we discussed before, the communicators image is more recognized and affirmed by the audience, then the credibility of its source is higher, and we can achieve better dissemination results. The emotional barriers between ideological and political educators and recipient have developed into a problem which needs ideological and political education to solve. In the new media environment, communication between people will show a strong hidden and secretive type in a certain extent. Contemporary ideological and political education of college students can achieve two-way communication with the new media, especially in the micro-Bo, QQ, Email, SMS and other communication environment, the informal way of expression can not only reflect the most real emotions, but also it can avoid the psychological barrier caused by " face to face, speech language of mental disorder " communication, which can greatly alleviate or even eliminate the gap between college students and educators.

\section{CONCLUSIONS}

Ideological and political education in higher education reflects the essence of socialism, so the new media meets the needs to foster the socialism of Chinese characteristics and the modern successors of socialism with Chinese characteristics, but it also can foster the main force for the great rejuvenation of the Chinese nation. New Media in the final analysis is only a tool, on the one hand it is essential, but on the other hand it is just a form of media, the soul of the ideological and political education theory is ideology itself. The first is the excellence of business, or that we should sincerely put ideological and political theory as a science, not as sensational way, and not as mere indoctrination. In short, the ideological and political education of new media is a systematic project, the basic elements must not be one-sided understanding, when we put natural law and advanced concepts of new media together, which must be able to meet the demands of the times, and foster the successors of socialism with Chinese characteristics.

\section{References}

[1] Ji Juhai. Study on the ideological and political education in Colleges and universities in the new media era [D]. Nanjing Normal University, 2013

[2] Chen Jun. Ideological and political education innovation research in the new media era [D]. Taiyuan University of Science and Technology, 2014

[3] Wu Qiong. Impact and innovation research of new media for ideological and political education [D]. Hefei University of Technology, 2013

[4] Lu Shuang. Study on Application of new media in the Recessive Ideological and political education in University [D]. Shanxi Normal University, 2013

[5] Feng Xin. Strategies and approaches study of ideological and political education in media literacy educators to explore in the new media era [J] reform and opening up, 2011, 06: 45. 